\title{
AN ANALYSIS STUDENT'S ABILITY IN WRITING DESCRIPTIVE TEXT OF SECOND SEMESTER OF ENGLISH EDUCATIONAL PROGRAM AT STKIP NURUL HUDA OKU TIMUR
}

\author{
Zulaikah, Eka Agustina, M. Muklas \\ Sekolah Tinggi Keguruan dan Ilmu Pendidikan (STKIP) Nurul Huda OKU Timur \\ Email: zulaikah@stkipnurulhuda.ac.id, ekaagustina@stkipnurulhuda.ac.id \\ mmuklas@stkipnurulhuda.ac.id
}

\begin{abstract}
This study was descriptive research. The objective this study was "to find out whether descriptive methode can analyse writing ability in second semester of English Educational Program at STKIP Nurul Huda OKU Timur'. The students' writing ability in descriptive text was analyzed based on score clasification. In this case, the highest score of 32 students in this class, get 75 which it considered the as in good level. While the lowest results get score 52 which it considered the as in average level. Then, the other students' get 54 until 74 mean score in terms of sub indicator in writing text they get was in which it also considered as in average and good level. Thus, generally, the students' mean score of writing ability particularly in writing descriptive text was 60 and it was considered as the average level of ability. Thus, from the data presentation, it can be concluded that the writing descriptive text skill of the second semester of English educational program in STKIP Nurul Huda was in average level.
\end{abstract}

\section{Keywords: Analysis, Writing Ability, Descriptive Text}

\begin{abstract}
Abstrak
Penelitian ini adalah penelitian deskriptif. Tujuan penelitian ini adalah "untuk mengetahui apakah metode deskriptif dapat menganalisis kemampuan menulis pada semester dua Program Pendidikan Bahasa Inggris di STKIP Nurul Huda OKU Timur". Kemampuan menulis siswa dalam teks deskriptif dianalisis berdasarkan klasifikasi skor. Dalam hal ini, nilai tertinggi dari 32 siswa di kelas ini, didapatkan 75 yang dianggap sebagai tingkat yang baik. Sedangkan hasil terendah mendapat skor 52 yang dianggap sebagai tingkat sedang atau biasa. Kemudian, siswa lain mendapatkan skor 54 hingga 74, rata-rata dalam hal sub indikator dalam teks tertulis yang mereka peroleh, yang juga dianggap sebagai tingkat sedang dan tingkat yang baik. Dengan demikian, secara umum, nilai ratarata kemampuan menulis siswa khususnya dalam menulis teks deskriptif adalah 60 dan itu dianggap sebagai tingkat kemampuan sedang atau biasa. Dengan demikian, dari penyajian data, dapat disimpulkan bahwa keterampilan menulis teks deskriptif semester kedua program pendidikan bahasa Inggris di STKIP Nurul Huda adalah tingkat sedang atau biasa.
\end{abstract}

\section{Kata Kunci: Analisis, Kemanpuan Menulis, Deskriptif Teks}




\section{A. Background}

English is one of foreign language. It has becomes very important in education. Because English language including to several language lesson in our country. Foreign language has several function such as: a. language as a system of communication for everyone, b. the most complex of man's tool, c. each language is structurally different system d. international communication and study of language. Foreign languange as a international language, it is used to communicate among people in the different country and also many countries. However, it can be an important to that it should be learned by the students.

In our country, English learned since elementary school. Because English is not our authentic language, so ordinary if the students are difficult to learn it. based on that statement, English learned with many methods to make students easily to learn English as their second language. One of method that helps the students to master of English is by using descriptive method.

Descriptive text is the text about the way of things, people, or places. In descriptive texts, the students can use imagination and percept-kive sense to make reader hear, taste, smell, see, and feel as they present a good word of the subject. P. Josep Canavan stated "students may be describing a sunset, an individual, or a sinking ship. Whatever the subject, a writer's purpose in description in the same; to appeal the imagination, the emotion, and the senses.

We know that English is not our authentic language, as a fact that mastery it was not easy. The proportions and ability of English language is important for young language learner. The proportions include vocabulary, pronunciation grammatical structure, and phonology, that can give the effect to the Englishlanguage skills; such as speaking,reading listening, and writing. Sometimes People easy to speak, read and listen about english but difficult to write.

Writing becomes the most difficult skill when it is learned by the foreign language learners. According to Rass (2001:30) said, "Writing is a difficult skill for native speakers and non-native speakers; because writers must be able write it in multiple issues such as organization, content, purpose, vocabularies, audience, and mechanics such as spelling, punctuation, and capitalization", it is because there are some aspects that the students should learn to make a good writing. 
Those aspects are grammar, vocabulary and mechanic. They have to understand those criteria well in order to produce a good writing. In teaching and learning process of writing, the teachers have an important role. According to Brown (2001): "writing is thinking process, because writing is a process of putting ideas down on paper to transform thought into words and give them structure and coherent organization".

In writing, students must understand and know about vocabulary, grammar, sentence connection sentence structure, etc. Sometimes the students can speak English fluently but they can not understand in Writing or making article. But the real, most of Indonesian students could not learn English well, especially in Writing. It is usually showed when they write article,paper, or thesis in English. Many students make mistake when they write essay or article. Not all students have some abilities in pouring the ideas when they write essay or article, it is because they do not have interest in studying writing ability.

This is also happened at The STKIP Nurul Huda exactly in the second semester of English educational program, they can write an essay or article, but many students got many problems, such as: they have many vocabularies but they could not pour it into a written text. Students less vocabularies so they can't write, they do not know in grammar, and many students were not interested in writing. Because writing activity was boring in their opinion, and they sometimes feel lazy to practice writing in English.

The writer did observation at The STKIP Nurul Huda OKU timur exactly in the second semester of English educational program . The writer found some problems why the students sometime lazy if they got writing lesson. Those trouble were: the students were lack of writing ability expecially in grammar, almost of them were lack of vocabulary and the students were lack of motivation in learning English. One way to improve students writing ability is the students have to be more active and study hard than the teacher and the students also have to be coincident. It can be tired in descriptive method. By using descriptive method, the writer would like to research the second semester of English educational Program in STKIP Nurul Huda as subject of this research. 
Based on explanation above, Writer is interested to do a research entitle “An Analysis Student's Ability in Writing Descriptive Text of Second Semester of English Educational Program at STKIP Nurul Huda OKU Timur”.

\section{B. Problem of the Study}

1. Limitation of the problem

In order in wrting more effective and effisient, the writer was limited only use descriptive text in teaching writing.

2. Formulation of the problem

Based on the limitation of the problem mentioned, the problem research is to know the analysis writing ability through descriptive Method.

3. The Objective of Study

Based on the problem above, the objective of this study is to find out whether descriptive methode can analyse writing ability in second semester of English Educational Program at STKIP Nurul Huda OKU Timur.

4. Significances of the Study

a. For the writer

By using this method perhaps for writer will get one solution to evaluate.

The writer will know what the advantages are by using descriptive method in teaching English language. And later, writer will choose this method as one of solution to evaluate.

b. For the teacher

The result of this research the teacher can evaluate clearly in teaching English language uses the descriptive method. This research can be given to the teacher as variation in teaching and learning English language.

c. For the students

The result of this research is expected can help the students to increase their writing ability.

\section{Literature Review}

1. Definition of Writing

According to Coulmas (2003:1) there are three meanings of writing can be distinguished. First, writing is a system of recording language by 
means of visible or tactile marks. Visible or tactile marks mean the writer can see the product of their writing by using their eyes. Second, writing is an activity of putting the ideas. The ideas are very needed in writing. Good ideas can add knowledge or information for the reader. Third, the result of writings' activity is text. It means that writing is not only communicative skill but also productive skill that can produce a text such as descriptive text, procedure text, report text and narrative text.

2. Types of Writing

Paragraphs, article and essays can be written in different types. A writer will choose a type depending on what she or he wishes to accomplish, what sort of material is to be discussed, and what kind of effect she or he wants to have on the reader. Generally speaking, there are four types of writing, though normally these types are mixed together.

a. Expository. Expository writing explains or informs. It talks about a subject without giving opinions. Expository writing's main purpose is to explain. It is a subject-oriented writing style, in which authors focus on telling you about a given topic or subject without voicing their personal opinions. These types of essays or articles furnish you with relevant facts and figures but do not include their opinions. This is one of the most common types of writing. You always see it in textbooks and how-to articles. The author just tells you about a given subject, such as how to do something.

b. Descriptive. Descriptive writing focuses on communicating the details of a character, event, or place. | Source Descriptive writing's main purpose is to describe. It is a style of writing that focuses on describing a character, an event, or a place in great detail. It can be poetic when the author takes the time to be very specific in his or her descriptions.

c. Persuasive. Persuasive writing tries to bring other people around to your point of view. Persuasive writing's main purpose is to convince. Unlike expository writing, persuasive writing contains the opinions and biases of the author. To convince others to agree with the author's point of view, persuasive writing contains justifications and reasons. It is often used in 
letters of complaint, advertisements or commercials, affiliate marketing pitches, cover letters, and newspaper opinion and editorial pieces.

d. Narrative. A narrative tells a story. There will usually be characters and dialogue. Narrative writing's main purpose is to tell a story. The author will create different characters and tell you what happens to them (sometimes the author writes from the point of view of one of the characters - this is known as first person narration). Novels, short stories, novellas, poetry, and biographies can all fall in the narrative writing style. Simply, narrative writing answers the question: "What happened then?"

3. Descriptive Text

Descriptive text is a text which is intended to describe a particular person, place or thing. The schematic structure of Descriptive text is divided into two: Identification and Description. Besides schematic structure, descriptive text also has its own linguistic features. Linguistic features of descriptive text are: use specific participant, written in present tense, use linking verbs, use adjectives, use relational and material processes (Derewianka, 1990; Gerot \& Wignell, 1994; Nafisah \& Kurniawan, 2007; and also Emilia, 2010). In writing description, while, it is possible to take time and set down details that will show with appropriate, to describe picture looks for example, what picture, what about, how many pictures, ect, to discribe someone the person height, shape of head, color of hair, look of eyes, ect. In order to be particular and interesting. We have to notice details and could to describe it in interperance.

4. The Elements of Writing

Althought the writing process has been analyzed different way, most of teachers would may agree in recognize least of following five general components, they are:

a. Developing Ideas. The topics that were given to the students were considered familiar to the students. However, in this research there were some students who unable to develop their ideas well. It might be because they did not understand how to develop the ideas. The students said that they had studied how to make a good descriptive writing text. 
However, in practice, they did not succeed in arrange a good descriptive text. according to Barnet and Stubbs (1990:105) “A good paragraph has unity (it makes one point, or it indicates where one unit of the topic begins and ends)". To have a paragraph unity a students have to support the ideas into the sentences.

b. Organizing ideas. Reep (2009:82) states that "a paragraph achieves coherence when the sentences proceed in a sequence that supports one point at a time. Transitional, or connecting, words and phrases facilitate coherence by showing the relationship between ideas and by creating a smooth flow of sentences". In organizing the ideas the students have to use two components of generic structure of writing descriptive, they are identification and description. It means that, in description component, the students have to describe parts, characteristics of the objects and qualities . Sometimes, the students cannot organize the paragraph well, it seems that they cannot develop the ideas of their writing well. Beside identification and description component, in organizing ideas the students also have to pay attention to the chronological order to their text. Chronological order is ordered by time; it uses to explain the process, for example where is drugs sell? The students can use: first, second, next, etc to explain about the future of the places. Chronological order also used to describe events period of time. In fact, only small numbers of the students used chronological order. The students confessed that these occurred because they did not write the outline before write the text and did not a list of ideas first. They directly wrote the ideas coming to their mind. So, it makes their texts did not organized well and many repetition of ideas presented.

c. Grammar. Gerot and Wignell (1994) state that grammar is a theory of a language, of how language is put together and how it works. This element consists of the discussion of grammatical form and syntactic pattern. In measuring the writing ability, a teacher tests the sensitivity to the grammatical patterns appropriate to the writing genre. Grammatical features of describing The tense that is frequently used in descriptive 
text is present tense. The description is from factual point of view (e.g. looks, writes, cooks, etc.).

d. Vocabulary. Writing vocabulary is all the words that can be employed in writing. Many written words did not commonly appear in speech, the writers generally use a limited set of words when communicating. According, Hadfield (2008:45) divides vocabulary into two kinds of vocabulary, there were :

1) Productive (active) vocabulary is words that they are able to produce themselves.

2) Receptive vocabulary (passive) is words that they understand but may never produce.

e. Mechanics. Mechanics is the use of the graphic conventions of the language. It refers to the appearance of words, to how they are spelled or arranged on paper. The example of mechanic is when writing the first word of a paragraph, it must be intended. The rules of mechanic try to make the writing seem consistent and clear. The convention may seem arbitrary. In fact, it was developed from thousand of experiences. The mechanic represents the economic and efficient way of writing. There is a discussion about punctuation in the mechanic. This subject is a little bit complicated. Some punctuation is cut-and dried, while the others fall into the area of usage or style. The purpose of taking punctuation in writing is making the text clearer and reading easier. There are four function of punctuation, those are: a) Classifying or enclosing (e.g. parentheses enclosing extraneous information). b) Separating (e.g. a period separating sentences). c) Impacting the meaning (e.g. a question mark making an otherwise declarative sentence interrogative) d) Connecting (e.g. a hyphen connecting a unit modifier). The function of punctuation mark is the basic rule governed and determined whether it is needed or not. The modern tendency is to punctuate the prevent misreading (open style) rather than to use all punctuation that is allowed by the grammatical structure (close style). Open style allows 
subjectivity, arbitrariness, and the use of some marks though it results in a more inviting product.

The role of authores editores subjectivity is crucial to make a wellpunctuate text. The main function of punctuations is to help the readers comprehend the intention of the write In short, mechanic is the use of language convention in writing. The convention is the rule of language. Punctuation is also discussion in mechanic. From the above, it can be seen that the writing process, as commonly conceived, is highly sophisticated skill combining a number of diverse elements, only some of which are strictly linguistics. In sum up, there are some aspects that a teacher should consider when s/he analyzes the students ${ }^{\text {ee }}$ writing text. The aspects are content, form, grammar, style and mechanics. All the components cannot be separated each other to produce a good writing. write well. Therefore, both punctuation and writing can not be sparate writing cannot be separated each other.

\section{Method}

1. Method of Research

In this research, the writer used descriptive method. Descriptive method is a research which use imagine to pour all of the ide from the writer. Usually most of people are intersted with the other people and as human being usually interested to other human being,often, in the conversation,one hear, 'what did she look?', 'what did they wear?' and for answer those questione, the people have to discribe it. When discribe something or someone, the writer has to gives the reader a pictures. To make the writing as good and real, the writer give some pictures in order to discribe the reader. This research had purpose to find out the analysis of writing ability at second semester of English Educational program at STKIP Nurul Huda OKU Timur.

2. Objective of The Research

Object of the research is problem that would be researched. The writer choose the second semester of English Educational Program at STKIP Nurul Huda OKU Timur as the object of this research. According to Sugiyono (2009:38), Object of the research is an attribute, character or value of person, 
object or activity which has a particular variation that state by researcher to be studied and taken conclusion then.

3. Source Of Data

In this research, data are classified into two, they are primary data and secondary data, that described as follows :

a. Primary Data

The primary data of this research is selected at second semester of English Educational Program.

b. Secondary Data

To complete the primary data, the writer also collected the supporting data. These data consist of :

1) Description about the pictures.

2) Internet and other relevant information.

4. Technique For Collecting Data

Technique of collection the data is how the writer collect and get the data. According to Suharsimi Arikunto (2006:150), there are six kinds of method technique of collecting the data: they are test, interview, questionaries, observation, rating scale and documentation. In this research, the writer used documentation as technique of collection the data. Nawawi (1991:95) state that" the documentation method is a method of collecting data conducted by classifying the written materials related to the problem of the study and used for obtaining the data by some variables such as magazine and books as the data". According to Arikunto (2002:158), "documentation method is a method to collect data in written source like books, magazine, documents, etc". The method used in preparing the data related to the object of this research is documentation method because the writer collected the data from the lecture and some students. In collecting the data, there are some steps should be done, they are: Give the pictures to students. Collect and correct the result from the students. Collecting all relevant information from books and internet website.

5. Technique for Analyzing Data

This research was focused on analyzing the writing ability in second semester of English Educational Program by using qualitative approach with 
descriptive method. To support the research, the writer used content analisis method. Content analysis connected to general set of techniques useful for analyzing and understanding collection of text. According to borg and gall (1983:511), content analysis is systematic and qualitative description of manifest content in communication and it is usually use to analyze the raw material of any from the written material such as in text book, novel, newspaper, magazine and advertisement and political speeches and often used conjunction observational studies. To analyze the data by using content analysis, the writers do the steps as follows:

a. Data processing

In this study, the writer used three techniques of data processing, they are:

1. Collecting

This process to collect all data that needed in this research.

2. Analyzing

This technique to analyze the sentences from student's writing.

b. Data analysis

Before all of the collecting data have been reported, the writers analyzed them. The writers analyzed the sentences from the student's writing. The analysis helps the writer to highlight some important conclusions of this research.

c. Analyzing students score

Based on the scores which were gotten from the test, the research calculated the scores so that the finding of the research was be revealed in form of the information related to the analysis of students' writing ability in descriptive text of the second semester of English Educational Program at STKIP Nurul Huda. Then, the scores were analyzed acording to the central tendency (mean, mode, and median) and standard deviation for the each aspects and hole aspect.

d. The writer give the score clasification

There are five level of the students' writing ability encompassing poor, fair, average, good, excellent, Harris (1969). 
Table 1 The students' score skill level

\begin{tabular}{|c|c|}
\hline Score Interval & Category \\
\hline $81-100$ & Classifield Excellent \\
\hline $61-70$ & Classifield Good \\
\hline $41-60$ & Classifield Average \\
\hline $21-40$ & Classifield Fair \\
\hline $0-20$ & Classifield Poor \\
\hline
\end{tabular}

Source: Harris. 1969

\section{E. Findings And Discussions}

Most important in the research is research finding and discussion. This chapter presented data presentation, data analysis and the discussion.

1. Research Findings

The finding consist of description of data. After the data had been collected from the sample of the research, the data was going to be described. In describing the data, it involves analyzing of the data.

2. The Description of Data

In order to collect the data, the writer conducted a test. The test given was writing descriptive text. The score of the test consist of five aspects. The aspects measured are developing ideas, organizing idea, grammar, vocabulary, and mechanic. After conducting the test the result in form of students' scores are tabulated as follows:

Table 2 Students' writing descriptive text score at five indicators

\begin{tabular}{|c|c|c|c|c|c|c|}
\hline Students & \multicolumn{5}{|c|}{ Aspect } & Score \\
\hline & $\begin{array}{c}\text { Developing } \\
\text { Ideas }\end{array}$ & $\begin{array}{c}\text { Organizing } \\
\text { Ideas }\end{array}$ & Grammar & vocabularies & mechanic & \\
\hline $\mathrm{AF}$ & 7 & 11 & 10 & 4 & 18 & 74 \\
\hline AR & 4 & 9 & 9 & 4 & 19 & 66 \\
\hline AT & 5 & 8 & 9 & 3 & 16 & 56 \\
\hline $\mathrm{DA}$ & 6 & 8 & 9 & 3 & 10 & 62 \\
\hline $\mathrm{DH}$ & 5 & 8 & 9 & 3 & 16 & 61 \\
\hline DL & 4 & 6 & 8 & 2 & 15 & 52 \\
\hline ER & 5 & 9 & 9 & 3 & 15 & 60 \\
\hline ID & 5 & 8 & 9 & 3 & 15 & 56 \\
\hline IR & 5 & 8 & 9 & 3 & 18 & 63 \\
\hline IV & 7 & 10 & 10 & 4 & 20 & 75 \\
\hline $\mathrm{JM}$ & 6 & 9 & 10 & 3 & 17 & 66 \\
\hline MM & 7 & 10 & 10 & 4 & 15 & 68 \\
\hline $\mathrm{MI}$ & 5 & 8 & 9 & 3 & 15 & 56 \\
\hline MA & 3 & 4 & 7 & 1 & 10 & 37 \\
\hline MW & 6 & 7 & 7 & 4 & 20 & 64 \\
\hline $\mathrm{NL}$ & 5 & 9 & 10 & 3 & 16 & 63 \\
\hline $\mathrm{RS}$ & 5 & 7 & 9 & 3 & 15 & 58 \\
\hline $\mathrm{RU}$ & 5 & 8 & 9 & 3 & 15 & 56 \\
\hline RA & 3 & 9 & 9 & 3 & 18 & 62 \\
\hline
\end{tabular}




\begin{tabular}{|c|c|c|c|c|c|c|}
\hline RP & 5 & 7 & 9 & 4 & 16 & 60 \\
\hline SU & 4 & 7 & 8 & 4 & 18 & 60 \\
\hline SW & 5 & 7 & 9 & 3 & 17 & 61 \\
\hline SA & 5 & 9 & 9 & 3 & 15 & 60 \\
\hline SAT & 6 & 7 & 10 & 3 & 17 & 63 \\
\hline SD & 5 & 8 & 9 & 3 & 15 & 56 \\
\hline SN & 6 & 9 & 9 & 3 & 16 & 63 \\
\hline UA & 5 & 8 & 9 & 3 & 15 & 56 \\
\hline WD & 6 & 8 & 10 & 3 & 17 & 62 \\
\hline WD & 6 & 8 & 10 & 3 & 17 & 62 \\
\hline WN & 5 & 7 & 10 & 3 & 16 & 60 \\
\hline YS & 5 & 9 & 9 & 3 & 15 & 60 \\
\hline YP & 4 & 6 & 8 & 3 & 16 & 54 \\
\hline & \multicolumn{7}{|c|}{ Jumlah } & & 1932 \\
\hline & \multicolumn{7}{|c|}{ Mean dandeviation } & 60,375 \\
\hline
\end{tabular}

Source : Result of Research. 2018

From the table above can be calculated the descriptive statistcs as follows :
a. Mean
$=60,375$
b. Mode
$=56$
c. Median
$=60,5$
d. Standard deviation $=6,603$

Next step the writer analyzed the data in each aspects to find out which aspects are good and which aspects are weak. The analysis of each aspect distributed in form of table as follows :

Table 3 Developing Ideas

\begin{tabular}{|c|c|c|c|c|c|}
\hline Total of real score & Mean & Mode & Median & SD & LEVEL \\
\hline 2062,5 & 57,25 & 53,57 & 57,14 & 7,72 & AVERAGE \\
\hline
\end{tabular}

Source : Result of Research. 2018

In terms of developing ideas, it was found that the mean score of writing ability of second semester of english educational program at STKIP Nurul Huda OKU Timur was 57,25, mode53,57, median 7.72 standart deviation 7.72 and categorized as Average level.

Table 4 Organizing idea

\begin{tabular}{|c|c|c|c|c|c|}
\hline Total of Real score & Mean & Mode & Median & SD & LEVEL \\
\hline 1828,57 & 57,14 & 57,14 & 57,14 & 9,60 & AVERAGE \\
\hline
\end{tabular}

Source : Result of Research. 2018

Then, In terms of developing ideas, it was found that the mean score of writing ability of second semester of English educational program at STKIP Nurul Huda OKU Timur was 57,14, mode57,14, median 57,14 standart deviation 9,60 and categorized as Average level. 
Table 5 Grammar

\begin{tabular}{|c|c|c|c|c|c|}
\hline Total of real score & Mean & Mode & Median & SD & LEVEL \\
\hline 2071,43 & 64,73 & 64,29 & 64,29 & 5,71 & GOOD \\
\hline
\end{tabular}

Source : Result of Research. 2018

In addition of grammar, it was found that the mean score of writing ability of second semester of English educational program at STKIP Nurul Huda OKU Timur was 57,14, mode57,14, median 57,14 standart deviation 9,60 and categorized as good level.

Table 6 Vocabulary

\begin{tabular}{|c|c|c|c|c|c|}
\hline Total of real score & Mean & Mode & Median & SD & LEVEL \\
\hline 2500 & 78,13 & 75 & 75 & 15,22 & EXELLENT \\
\hline
\end{tabular}

Source : Result of Research. 2018

The next, in vocabulary, it was found that the mean score of writing ability of second semester of English educational program at STKIP Nurul Huda OKU Timur was 78,13, mode 75, median 75 standart deviation 15,22 and categorized as exellent level.

Table 7 Mechanic

\begin{tabular}{|c|c|c|c|c|c|}
\hline Total of real score & Mean & Mode & Median & SD & LEVEL \\
\hline 1832,14 & 57,25 & 53,57 & 57,14 & 7,72 & AVERAGE \\
\hline
\end{tabular}

Source : Result of Research. 2018

Furthermore, in terms of mechanics, it was found that the mean score of writing ability of second semester of English educational program at STKIP Nurul Huda OKU Timur was 78,13, mode 75, median 75 standart deviation 15,22 and categorized as good level.

3. Discussion

From the data presentation in general result found that the students' mean score in writing descriptive text is 60,375 and according to the score clasification theory by Harris (1969) categorized as average. The scores were analyzed acoording to the central tendency (mean, mode, and median) and standart deviation come from five aspects they were developing idea, organizing idea, grammar, vocabulary, and mechanic.

Beside the data was analyzed in general, each aspect was also being analyzed. First is from the aspect of developing ideas. There are two indicators in this aspect, they are paragraph unity and coherence. The paragraph unity itself had the sub indicators consists of topic, topic sentence, and concluding sentence. And the coherence sub indicators consists of 
sentence hold together. With the guide of indicators and sub indicators, the writer can collect and analyze the data. The finding shows that the mean score in developing ideas aspect is 57,25, mode 53,57, median 57,14, standart deviation 7,72 and according to the score clasification theory categorized as average level.

The second aspect to be analyzed is Organizing idea. There are 3 indicators in this aspect, they were Coherence, Identification, Description. The coherence indicators has the sub indicators consists of repeat key from sentence to sentence, use pronoun for preceding key term, use demonstrative adjective, uses connecting words. Next identification indicator has the sub indicators consists of Identify the topic of free sex,social media and drugs, describe the complete features of the topic. And the last description indicators has the sub indicators consists of part, qualities, and characteristic. With the guide of indicators and sub indicators, the researcher can collect and analyze the data. The finding shows that the mean score in organizing idea aspect is 57,14, mode 57,14, median 57,14, standart deviation 9,60 and according to the score clasification theory the categorized as average level. Compared with the previous aspect can be seen that the mean score of this aspect was higher than developing ideas aspect.

The third aspect to be analyzed is Grammar. There were two indicators in this aspect, they were simple present tense and adjective words. In Simple present tense indicators has the sub indicators consists of; to describe, actions or conditions that are usual, habitual or permanent, to state general /truth, for future action on schedule time, for future action in certain time,relational verbs used when classifying and describing appearances /qualities and parts/functions of phenomena (is, are, has, have). The next Adjective words indicators has the sub indicators consists of used to add extra information to noun sand may be technical, everyday or literally, depending on the text. this aspect of indicators and sub indicators, the writer can collect and analyze the data. The finding shows that the mean score in grammar aspect is 64,73 mode 64,29 , median 64,29 , standart deviation 5,71 and according to the score clasification theory the categorized as good level 
compared with the previous aspect can be seen that the mean score of this aspect is higher than developing ideas and organizing idea aspects.

The next aspect was vocabulary. This aspect consist of two indicators they were word choices and In sub indicator of word choices is choose the appropriate and accurate words to express ideas.In sub indicator of word choices is choose the appropriate and accurate words to express ideas.Then in terms of of In sub indicator of word choices is 200 words. With the guide of indicators and sub indicators, the writer can collect and analyze the data. the result of collect and analyze the data finding and to shows that the mean score in vocabulary aspect is 78,13 , mode 75 , median 75 , standart deviation 15,22 and according to the score clasification theory the categorized as exellent level compared with the previous aspect can be seen that the mean score of this aspect is higher than grammar, organizing ideas and developing ideas aspect.

The last aspect was mechanic. the result of collect and analyze the data finding and to shows that the mean score in mechanic aspect was 57,25, mode 53,57, median 57,14, standart deviation 7,72 and according to the score clasification theory the categorized as average level compared with the previous aspect can be seen that the mean score of this aspect is less from organizing ideas, same as developing ideas but higher than grammar and vocabulary.

\section{F. Conclusions And Suggestions}

1. Conclusions

The objectives of this study were to identify the cohesion found and also the most frequently of correctly and incorrectly used in descriptive text that written by second semester of English educational program in STKIP Nurul Huda OKU Timur. Based on the findings, the conclusion is drawn from the analysis descriptive texts are developing ideas, organizing ideas, grammar, vocabulary, and mechanic. Based on the statement of the research problem, the result shows: The first point is that students' writing ability in descriptive text of the second semester of English educational program in 
STKIP Nurul Huda in terms of three out of five components (developing ideas, organizing ideas, and mechanic) were considered as the average level, grammar was considered as the good level and vocabulary was considered exellent. Moreover, the students' writing ability in descriptive text was analyzed based on score clasification. In this case, the highest score of 32 students in this class, get 75 which it considered the as in good level. While the lowest results get score 52 which it considered the as in average level. Then, the other students' get 54 until 74 mean score in terms of sub indicator in writing text they get was in which it also considered as in average and good level. Thus, generally, the students' mean score of writing ability particularly in writing descriptive text was 60 and it was considered as the average level of ability. Thus, from the data presentation, it can be concluded that the writing descriptive text skill of the second semester of English educational program in STKIP Nurul Huda was in average level. Furthermore, on the research, the last point is that there are five aspects in assessing aspects toward the students' writing ability in descriptive text of the second semester of English educational program in STKIP Nurul Huda. They are developing ideas, organizing ideas, grammar, vocabulary, and mechanic in which vocabulary was becoming the component which become the strength of students' writing ability which the students got the highest mean score 78. It was indicated that this part mainly affect the students' writing descriptive text ability while the weakness came from organizing ideas aspect. In this aspect the mean score was 57,14 which is the lowest of all aspects. Thus, from the data presentation, it can be concluded that the writing descriptive text skill of the second semester of English educational program in STKIP Nurul Huda was in exellent level.

2. Suggestion

Based on the conclusion presented in the previous sub-chapter, the writer gave some suggestions for the teacher, students, and other writer about the English teaching especially in teaching writing descriptive text.

a. For the Teachers 
The teachers, they should develop their method in teaching writing especially teaching writing descriptive text. Analyzing students' work is one of methods that they can apply to find out the students' strength and weakness in writing ability especially in descriptive text because it is important to acknowledge the students' strength and weakness so that the teacher can teach effectively.

b. For the Students

The students should improve their ability in constructing a descriptive paragraph with the right organizing ideas aspect. Somehow they still have to keep developing their writing ability especially in descriptive text in other aspects that support their writing so that their achievement also can be enhanced.

c. For Other Writer

The writer hopes that this study will useful for the readers. If they will be a study investigates the similar topic with the writer topic. The writer expects that this research will be broader field by exploring others variables. In this study, the writer just gained teaching writing by using descriptive text. Therefore the writer suggests for other writer later to write their ability in writing based on their experiences, vacation, and et al.

\section{References}

Arikunto, Suharsimi. 2006, Prosedur Penelitian. Jakarta: Rineka Cipta 2002. Prosedur penelitian. Jakarta: Rineka Cipta.

Azar, Betty S. 1999. Understanding and using English grammar. New York: Longman.

Barnet, Sylvan and Marcia Stubbs. 1990. Practical Guide to Writing: with

Brown, Douglas. H. 2001. Teaching by Principles. An Interactive Approach to Language Pedagogy. (2nd ed). New York: Addison Wesley Longman, Inc.

Coulmas, Florian. 2003. Writing Systems an introduction to their linguistic analysis. Cambridge: Cambridge University Press.

Derewianka, B. 1990. Exploring how texts work. Newton: PETA.

Doyle,W. 1986. Classroom organization and management. In M. Witrrock (Ed), Handbook of Research on Teaching. New york: Macmillan.

Emilia, Emi. 2010. Teaching Writing, Developing Critical Learners. Bandung: Rizqi Press. 
Gerot, L., and Wignell, P. 1994. Making sense of Functional Grammar. Australia: Gerd Stabler.

Hadfield, Jill; Hadfield, Charles. 2008. Introduction to Teaching English. Additional Readings (6th ed). New york: Addison Wesley Longman, Inc.

Harris, D. P. 1969. Testing English as a Second Language. McGraw-Hill: New York.

Nafisah, N., and Kurniawan, E. 2007. Writing for General Commucication. Bandung: UPI Press.

Nawawi, Hardi. 1991. Metode penelitian bidang sosial. Yogyakarta: Gajahmada University Press.

Reep, Diana c. 2009. Technical Writing: Principles, Strategies, Journal English Language Teaching (ELT) Volume 1 Nomor 2, Juli 201314 and Readings. New York: Pearson Education.

Sugiyono. 2009. Metode penelitian pendidikan: pendekatan kuantitatif, kualitatif, dan R\&D. Bandung: Alfabeta.

Borg, W. R. \& Gall,M.G. 1983. Education Research An Introduction. New York : Longman

Rass, R. Abu. 2001. Integrating reading and Writing for Effective Language Teaching. English Teaching Forum. Vol 10. 